\title{
A role for docosahexaenoic acid- derived neuroprotectin D1 in neural cell survival and Alzheimer disease
}

\author{
Walter J. Lukiw, ${ }^{1}$ Jian-Guo Cui, ${ }^{1}$ Victor L. Marcheselli, ${ }^{1}$ Merete Bodker, ${ }^{1}$ Anja Botkjaer, ${ }^{1}$ \\ Katherine Gotlinger, ${ }^{2}$ Charles N. Serhan, ${ }^{2}$ and Nicolas G. Bazan ${ }^{1}$
}

${ }^{1}$ Louisiana State University Neuroscience Center of Excellence, Louisiana State University Health Sciences Center, School of Medicine, New Orleans, Louisiana, USA. ${ }^{2}$ Center for Experimental Therapeutics and Reperfusion Injury, Brigham and Women's Hospital, Harvard Medical School, Boston, Massachusetts, USA.

\begin{abstract}
Deficiency in docosahexaenoic acid (DHA), a brain-essential omega-3 fatty acid, is associated with cognitive decline. Here we report that, in cytokine-stressed human neural cells, DHA attenuates amyloid- $\beta$ (A $\beta$ ) secretion, an effect accompanied by the formation of NPD1, a novel, DHA-derived 10,17S-docosatriene. DHA and NPD1 were reduced in Alzheimer disease (AD) hippocampal cornu ammonis region 1, but not in the thalamus or occipital lobes from the same brains. The expression of key enzymes in NPD1 biosynthesis, cytosolic phospholipase $A_{2}$ and 15-lipoxygenase, was altered in AD hippocampus. NPD1 repressed A $\beta 42$-triggered activation of proinflammatory genes while upregulating the antiapoptotic genes encoding Bcl-2, Bcl-xl, and Bfl-1(A1). Soluble amyloid precursor protein- $\alpha$ stimulated NPD1 biosynthesis from DHA. These results indicate that NPD1 promotes brain cell survival via the induction of antiapoptotic and neuroprotective gene-expression programs that suppress $A \beta 42$-induced neurotoxicity.
\end{abstract}

\section{Introduction}

The decline of memory and cognition in Alzheimer disease (AD) is underlain by untimely synaptic loss, enhanced inflammatory signaling, the progressive deposition of senile plaques and neurofibrillary tangles, and neuronal degeneration. The accumulation of extracellular amyloid- $\beta(A \beta)$ peptide derived from the transmembrane glycoprotein $\beta$-amyloid precursor protein ( $\beta$ APP) in the limbic system via $\beta$ - $\gamma$-secretase cleavage is characteristic of $\mathrm{AD}$, although there is still debate as to whether or not $\mathrm{A} \beta$ accumulation and its consequences fully explain the $\mathrm{AD}$ phenotype. $\mathrm{A} \beta$ peptides promote proinflammatory responses and are activators of neurotoxic pathways that lead to brain cell dysfunction and death (1-3). These events include enhanced excitotoxicity via increased calcium flux into neurons, activation of microglia, overproduction of reactive oxygen species and proinflammatory cytokines, and an overall oxidative stress response in the brain (2-4). In contrast, a soluble amyloid precursor protein- $\alpha$ $(\mathrm{sAPP} \alpha)$ peptide, generated from $\beta$ APP via the $\alpha$-secretase pathway, decreases the production of $A \beta$ peptides and elicits both neurotrophic and synaptotrophic effects.

Docosahexaenoic acid (DHA), a dietary essential omega-3 fatty acid concentrated in membrane phospholipids at synapses and in retinal photoreceptors $(2,5,6)$, is decreased in $\operatorname{AD}$ brain $(7,8)$. This deficiency may be due to enhanced free radical-mediated lipid peroxidation $(9,10)$, decreased dietary intake, and/or

Nonstandard abbreviations used: $A \beta$, amyloid- $\beta$; AD, Alzheimer disease; $\beta$ APP, $\beta$-amyloid precursor protein; CA1, cornu ammonis region 1 ; CEX-1, chemokine exodus protein 1; $\mathrm{CPLA}_{2}$, cytosolic PLA 2 ; DHA, docosahexaenoic acid; E/FGF, epidermal and fibroblast growth factor; GFAP, glial fibrillary acidic protein; HN, human neural (cell); HNMM, HN cell maintenance medium; LC-PDA-ESI-MS-MS, liquid chromatography-photodiode array-electrospray ionization-tandem mass spectrometry; 15-LOX, 15-lipoxygenase; NPD1, 10,17S-docosatriene, neuroprotectin D1; NSF-1, neural survival factor-1; $\mathrm{PLA}_{2}$, phospholipase $\mathrm{A}_{2}$; $\mathrm{sAPP} \alpha$, soluble amyloid precursor protein- $\alpha$. Conflict of interest: The authors have declared that no conflict of interest exists.

Citation for this article: J. Clin. Invest. 115:2774-2783 (2005).

doi:10.1172/JCI25420. impaired liver DHA shuttling to the brain (11). Decreased DHA serum content correlates with cognitive impairment (12-16). Moreover, epidemiologic studies suggest neuroprotective consequences of diets enriched in omega-3 fatty acids (10, 17-21). Using an AD mouse model, it was recently shown that dietary DHA counteracts $A \beta$ production, accumulation, and downstream toxicity (22).

To explore the mechanism(s) through which DHA participates in $\mathrm{AD}$ pathophysiology, we have studied unesterified $\mathrm{DHA}$, which is liberated by a stringently regulated phospholipase $\mathrm{A}_{2}\left(\mathrm{PLA}_{2}\right)$ and is subsequently converted into $10,17 S$-docosatriene via a 15-lipoxygenase-like (15-LOX-like) enzyme. We recently characterized 10,17S-docosatriene (NPD1) in mouse brain ischemia/ reperfusion and identified and characterized its neuroprotective properties (5). The biological activity of NPD1 in retinal pigment epithelial cells is highlighted by potent antiapoptotic and antiinflammatory actions, and we termed this bioactive DHA-derived lipid mediator neuroprotectin D1 (NPD1) (6). Thus in the present work we examined the interrelationship between human neural (HN) cell-derived $\mathrm{A} \beta 42, \mathrm{sAPP} \alpha$, and NPD1 signaling, studied their effects on the aging and fate of $\mathrm{HN}$ cells in primary culture, and measured NPD1 content in AD brain. Our present results indicate that endogenous DHA-derived NPD1 is a potent regulator of an intrinsic neuroprotective, antiinflammatory, and antiapoptotic gene-expression program that promotes survival in stressed human brain cells.

\section{Results}

$D H A$ downregulates secretion of $A \beta$ peptides from aging $H N$ cells and is the precursor of NPD1. HN cells, a primary coculture of human neurons and glia, are a useful in vitro test system to study stress mechanisms during human brain cell development, aging, and $\mathrm{AD}(3)$ (Figure $1 \mathrm{~A})$. As indicated by $\beta \mathrm{III}$ tubulin and glial fibrillary acidic protein (GFAP) immunostaining, these cultures are mixtures of approximately equal numbers of neurons and 

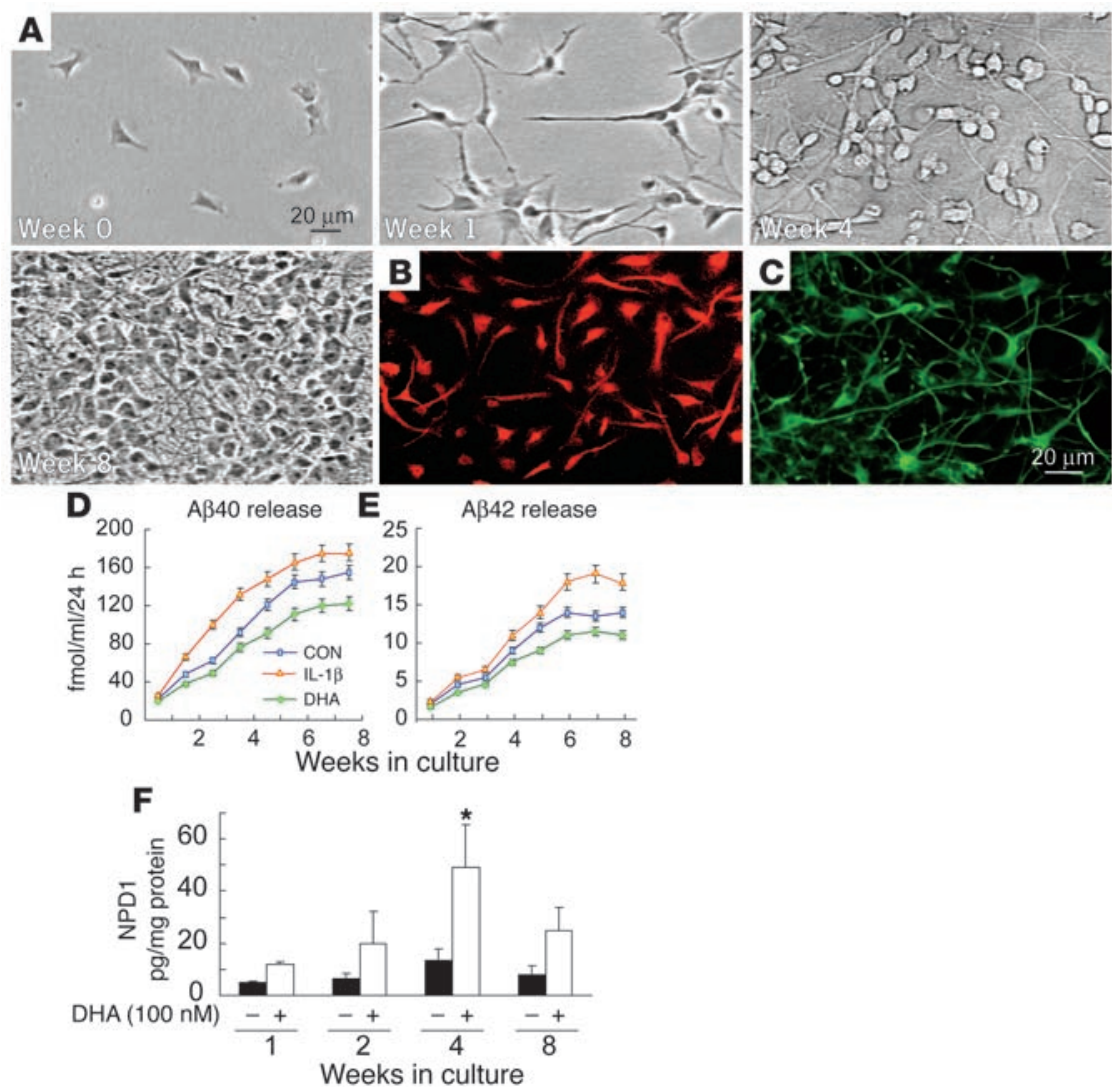

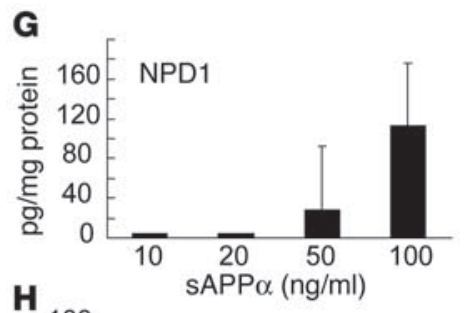

H
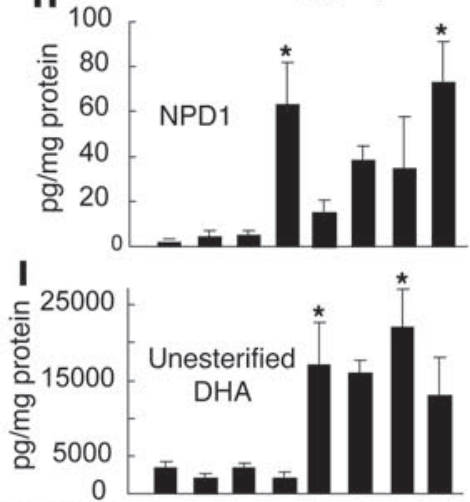

$\mathrm{A} \beta 4225 \mu \mathrm{M}-+--++-$ $\mathrm{sAPP} \alpha 20 \mathrm{ng} / \mathrm{ml}-{ }_{-}+-{ }_{-}$ $\mathrm{SAPP} \alpha 100 \mathrm{ng} / \mathrm{ml}-{ }_{-}+-{ }_{-}+$

$\mathrm{DHA} 50 \mathrm{nM}----++++$

\section{Figure 1}

DHA attenuates A $\beta$ peptide secretion and serves as the precursor for NPD1 biosynthesis; meanwhile, sAPP $\alpha$ activates NPD1 formation. (A) HN cells were grown for up to 8 weeks. (B and $\mathbf{C}$ ) After 4 weeks of culture, aging HN cells displayed approximately equal populations of neurons and glia and stained positive with the (red fluorescent) neuron-specific marker $\beta$ III tubulin (6) (B) and the (green fluorescent) glia-specific marker GFAP (C). ( $D$ and E) HN cells in culture normally release $A \beta 40$ and $A \beta 42$ peptides over 8 weeks of aging. Secretion by HN cells of $A \beta 42$ peptide was approximately one-tenth that of $A \beta 40$ peptide; IL-1 $\beta(10 \mathrm{ng} / \mathrm{ml}$ in modified HNMM; see ref. 3$)$ increased, and DHA decreased, the release of both $A \beta 40$ and $A \beta 42$ peptides into the cell culture medium. CON, control. (F) DHA (100 nM) induced NPD1 biosynthesis in HN cells, and this induction was age-dependent. (G-I) HN cells incubated in the presence of $10,20,50$, and $100 \mathrm{ng} / \mathrm{ml}$ of sAPP $\alpha$ showed dose-dependent upregulation of NPD1 formation (G); HN cells incubated with SAPP $\alpha$ (at 20 and $100 \mathrm{ng} / \mathrm{ml}$ ) and/or DHA (at $50 \mathrm{nM}$; even in the presence of A 342 ) also displayed upregulated production of NPD1 (H and I). ${ }^{*} P<0.05$ (ANOVA).

glia under our growth conditions at 4 weeks of development (Figure 1, B and C). Interestingly, amyloidogenic $A \beta$ peptides were progressively secreted from $\mathrm{HN}$ cells into the incubation medium throughout 8 weeks of culture (Figure 1, D and E). The ratio of $\mathrm{A} \beta 40$, a resident peptide of $\mathrm{AD}$ blood vessels, to $A \beta 42$, which aggregates at lower concentrations than $A \beta 40$ and is enriched within the amyloid plaque of $\operatorname{AD}(23,24)$, was about 10:1 throughout this 8-week period. To determine the effect of cytokine-mediated stress on aging $\mathrm{HN}$ cells, $\mathrm{A} \beta 40$ and $\mathrm{A} \beta 42$ peptide release was assayed in the incubation medium after addition of IL-1 $\beta$, a potent inducer of reactive oxygen species and a promoter of oxidative stress $(3,25)$. We found a time-dependent release of both $A \beta 40$ and $A \beta 42$ peptides as a function of number of weeks in culture. While soluble $A \beta$ peptide secretion from $\mathrm{HN}$ cells was enhanced in the presence of IL-1 $\beta$, parallel experiments with DHA in the culture medium showed attenuation of $\mathrm{A} \beta$ peptide release (Figure $1, \mathrm{D}$ and $\mathrm{E}$ ).

We next found that in HN cells, DHA was used as a precursor of NPD1 biosynthesis (Figure 1F). We observed an approximately 5 -fold increase in NPD1 appearance at 4 weeks of culture; at 8 weeks, the concentration of this oxygenated DHA derivative was about half that observed at 4 weeks (Figure 1F). Notably, during oxidative stress in human retinal cells and ischemia/ reperfusion in brain, NPD1 elicits neuroprotection $(5,6)$. These observations suggest that in aging $\mathrm{HN}$ cells, attenuation of the potentially neurotoxic $\mathrm{A} \beta$ peptide release by $\mathrm{DHA}$ could be mediated, at least in part, by NPD1.

sAPP $\alpha$ induces NPD1 biosynthesis. Because DHA mediated the downregulation of $A \beta 40$ and $A \beta 42$ release and stimulated NPD1 production in HN cells, we next explored the possibility that NPD1 biosynthesis might be affected by the neurotrophic peptide SAPP $\alpha$, a 612-amino acid fragment derived from $\alpha$-secretase-mediated cleavage of $\beta$ APP, which appears to be neurotrophic $(23,24)$. sAPP $\alpha$ promotes neuritogenesis and long-term survival of hippocampal and cortical neurons in culture and protects brain cells against the toxicity of $A \beta 40$ and $A \beta 42$ peptides and excitotoxic and ischemic injury both in cell cultures and in vivo $(23,26,27)$. It is important to note that the sAPP $\alpha$ generated via the $\alpha$-secretase pathway does not give rise to the shorter amyloidogenic $\mathrm{A} \beta$ peptides; hence, the shunting of $\beta \mathrm{APP}$ into the 

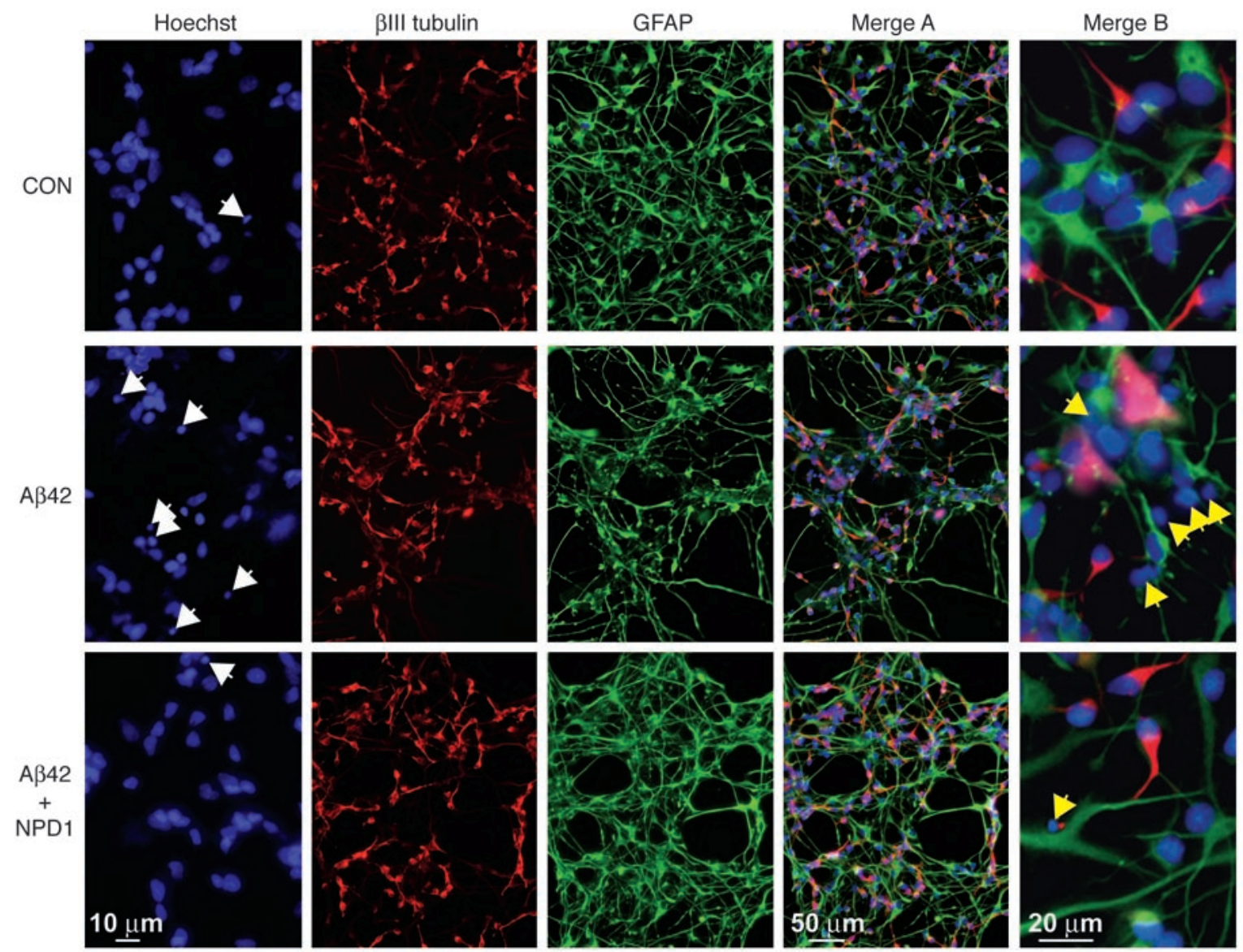

Figure 2

A 342 -induced apoptosis is inhibited by NPD1 in HN cells. After 3 weeks in culture, $\mathrm{HN}$ cells were treated with DMEM/F12 (control), A 342 (8 $\mu \mathrm{M})$ in DMEM/F12 (A $\beta 42)$, or A $342(8 \mu \mathrm{M})$ plus NPD1 (50 nM) (A $342+N P D 1)$ in DMEM/F12 for 3.5 days, then stained with Hoechst 33258 (Hoechst), anti- $\beta$ III tubulin ( $\beta$ III tubulin), and anti-GFAP (GFAP), and all 3 stains were imaged together (merge A). As revealed by Hoechst staining, in controls, relatively few compact nuclei were observed; in A $\beta 42$-treated cells, many compact nuclei were seen (white arrows). In A $\beta 42-$ treated cells, neurons and glia clumped together with condensed cytoplasm and damaged nuclei, and both $\beta$ III tubulin and GFAP staining was reduced (compare merges of control, A $\beta 42$, and A $\beta 42+N P D 1$-treated cells). When NPD1 was added to A $\beta 42$-treated cells, Hoechst staining revealed many fewer compacted nuclei. Each field under columns marked $\beta$ III tubulin, GFAP, and merge A represents approximately $0.1 \mathrm{~mm}^{2}$. A comparison of control, A 342 -treated, and A $\beta 42+$ NPD1-treated HN cells at higher magnification, stained with Hoechst 33258 (blue), anti- $\beta$ III tubulin (red), and anti-GFAP (green), shows that A $\beta 42$-induced apoptosis is associated with both neuronal and glial nuclei (merge B), and that A $\beta 42+N P D 1-$ treated $\mathrm{HN}$ cells show significantly decreased numbers of compacted apoptotic nuclei (yellow arrows).

$\alpha$-secretase pathway may have a beneficial effect by the relative lowering of $A \beta$ peptide levels $(24,26,28,29)$. We observed a dosedependent NPD1 induction by sAPP $\alpha$ (Figure 1G). For the additivity experiments with DHA and sAPP $\alpha$ (Figure 1, H and I), we selected concentrations of SAPP $\alpha$ that elicited a small $(20 \mathrm{ng} / \mathrm{ml})$ and a larger $(100 \mathrm{ng} / \mathrm{ml})$ NPD1 induction. We next found that sAPP $\alpha$ at 20 and $100 \mathrm{ng} / \mathrm{ml}$, in the presence of $50 \mathrm{nM}$ added DHA, induced NPD1 abundance 2.3- and 5-fold, respectively, over that in controls treated with DHA alone (Figure 1, H and I). sAPP $\alpha$ at $20 \mathrm{ng} / \mathrm{ml}$ in the absence of added DHA elicited negligible NPD1 synthesis; however, at $100 \mathrm{ng} / \mathrm{ml}$, sAPP $\alpha$ stimulation strongly promoted NPD1 synthesis in the absence of added DHA. These results indicate that some of the neurotrophic activity of sAPP $\alpha$ may be elicited, at least in part, by an upregulation in the biosynthesis of DHA-derived NPD1. This may be a complementary cellsurvival mechanism activated early in AD pathogenesis. SAPP $\alpha$ may activate NPD1 biosynthetic enzymes $\mathrm{PLA}_{2}$ and/or a 15-LOX- like enzyme integral to NPD1 biosynthesis from DHA (5). It is interesting that muscarine, a positive regulator of $\mathrm{PLA}_{2}$, is also a potent inducer of SAPP $\alpha$ in human neuroblastoma SH-SY5Y cells $(30,31)$; therefore, the enzymatic pathways involving PLA $_{2}$-mediated DHA and NPD1 biosynthesis may exhibit positive feedback regulation through sAPP $\alpha$. SAPP $\alpha$ also appears to protect neural cells against the proapoptotic action of thapsigargin, an inhibitor of the endoplasmic reticulum $\mathrm{Ca}^{2+}$-ATPase, and the adverse effect of thapsigargin can be abolished in cells overexpressing antiapoptotic Bcl-2 (23). A 342 elevated NPD1 levels in the presence of added DHA (Figure $1 \mathrm{H}$ ). This action of $A \beta 42$ peptide may represent a cytoprotective response of brain cells when confronted with a peptide that triggers oxidative stress. The unesterified DHA pool size assessed by liquid chromatography-photodiode array-electrospray ionization-tandem mass spectrometry-based (LC-PDA-ESI-MS-MS-based) lipidomic analysis $(5,6)$ (Figure 1I) showed that neither $\mathrm{A} \beta 42$ nor sAPP $\alpha$ was able to promote unester- 
A
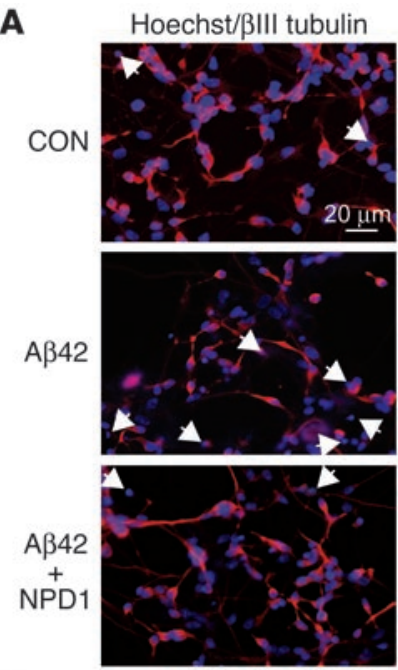

B

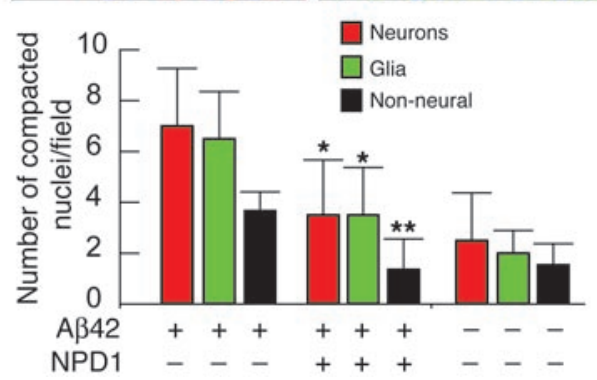

Hoechst/GFAP
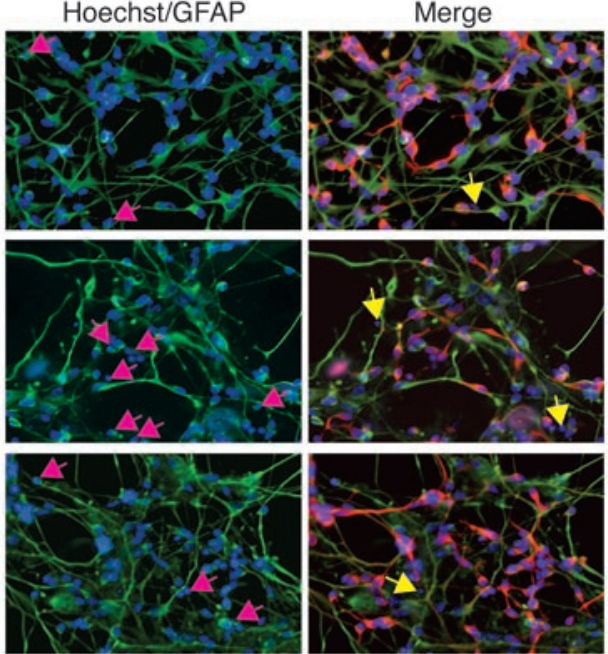

\section{Figure 3}

A 342 -induced apoptosis is associated with both neurons and glia. (A) Compacted nuclei were associated with both neurons (white arrows) and glia (pink arrows), and with non- $\beta$ III tubulin- or non-GFAPstaining cells (non-neural cells; yellow arrows). (B) Apoptosis, as monitored by the presence of compacted nuclei of no more than $0.5 \mu \mathrm{m}$ diameter $(5,6)$ after Hoechst 33258 staining, was significantly suppressed by NPD1. Analysis of numbers of compacted nuclei per field in both neurons (red bars) and glia (green bars) shows that these were significantly attenuated in the presence of $A \beta 42+N P D 1$ when compared with A $\beta 42$ alone; black bars indicate abundance of compacted nuclei associated with non- $\beta$ III tubulin-staining/non-GFAP-staining cells. $n=16 .{ }^{*} P<0.01$ and ${ }^{\star \star} P<0.05$ versus controls (ANOVA). ified DHA pool-size changes, indicating that a tight regulation of unesterified DHA may take place when sAPP $\alpha(100 \mu \mathrm{M})$ activates NPD1 production in the absence of added exogenous DHA (Figure 1I). Note that in instances where DHA was added to the $\mathrm{HN}$ cell culture medium, the presence of $\mathrm{A} \beta 42$ peptide did not modify its cellular pool size.

Neuroprotective activity of NPD1 in HN cells. Because A $\beta 42$ peptides promote apoptosis and cell death in both neurons and glia $(1,32)$, we next investigated the ability of NPD1 to protect HN cells against $\mathrm{A} \beta 42$-induced cytotoxicity. For this purpose, 3-weekold $\mathrm{HN}$ cells were incubated for an additional 3.5 days in serumfree $\mathrm{HN}$ cell maintenance medium (HNMM) made $8 \mu \mathrm{M}$ in $\mathrm{A} \beta 42$ peptide. Except for the experiments depicted in Figure 1, D-F, $\mathrm{HN}$ cells used in these studies were used at a developmental stage of 3-4 weeks in culture, at which time there were approximately equal populations of neuronal and glial HN cells (Figure 1, A-C). Because selective cell loss may take place in older HN cell cultures (when neuronal cells drop out), the use of HN cells at a fixed age (and 50:50 neuronal/glial populations) was selected to minimize this possibility. Apoptosis was found to occur in both neurons and glia (Figures 2 and 3 ). When NPD1 (50 nM) was added to this test system, NPD1 protected both neurons and glia from A $\beta 42$ directed apoptosis, as evidenced by quantification of Hoechst 33258 staining of compacted nuclei in control, A $\beta 42$-treated, and

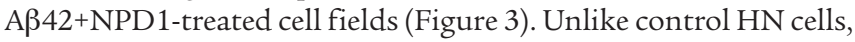
$\mathrm{A} \beta$-treated HN cells also exhibited retracted neurites; however, when treated with NPD1, cells assumed extended neurites and an overall morphology resembling that of control cells (Figure 3).

DHA and NPD1 activate a neuroprotective gene-expression program. We next explored proinflammatory and apoptosis-related geneexpression patterns in 4-week-old $\mathrm{HN}$ cells after exposure to $\mathrm{A} \beta 42$,
DHA, and NPD1 using DNA array-based human genome expression profiling (Affymetrix). We chose to focus on the inducible expression of the proinflammatory cytokines IL-1 $\beta$ and chemokine exodus protein 1 (CEX-1), the prostaglandin synthase COX-2, the TNF- $\alpha$-inducible proinflammatory element B94 $(33,34)$, and TNF- $\alpha$, whose RNA levels are upregulated in the brains of AD patients (33), and 5 members of the Bcl-2 gene family, 3 of which are antiapoptotic [Bcl-xl, Bcl-2, and Bfl-1(A1)] and 2 of which are proapoptotic (Bax and Bik; refs. 23, 35). In the experiments presented in Figure 4, HN cells were treated with A $342(25 \mu \mathrm{M})$ and DHA or NPD1 (each $50 \mathrm{nM}$ ambient) for 18 hours. We used experimental cutoff parameters combining 2 stringent criteria for up- or downregulated genes: (a) changes in gene expression of 2-fold or greater difference over controls that (b) achieved significance of $P$ less than 0.05 (ANOVA). Results were graphed as truncated "volcano plot" representations (Figure 4, A-C) using GeneSpring 7.2 algorithms (Silicon Genetics). As shown in Table 1, A $\beta 42$ markedly upregulated a complex proapoptotic and proinflammatory gene-expression program. These analyses indicated significant A $\beta 42$-mediated upregulation in the expression of a family of genes encoding the cytokines IL- $1 \beta$, CEX-1, and TNF- $\alpha$, COX-2, B94, and the proapoptotic Bax and Bik proteins (35-37). DHA and NPD1 each showed upregulation of Bcl-xl, Bcl-2, and Bfl-1(A1), neuroprotective members of the $\mathrm{Bcl}-2$ gene family, and relative downregulation of Bax and Bik, proapoptotic members of the Bcl-2 gene family (Table 1). Bax and Bik were upregulated 3.2- and 2.8-fold (each $P<0.05$ ), respectively, in A $\beta 42$-treated cells over age-matched control cells, and these enhanced RNA levels were driven to the status of "no significant change" after treatment with DHA or NPD1 (Table 1). The antiapoptotic Bcl-2 family member Bfl-1(A1) was upregulated by DHA and NPD1 to about 4- and 6-fold over con- 


\section{Table 1}

Changes in gene-expression patterns in A $342-$, DHA-, or NPD1stressed HN cells

\begin{tabular}{|c|c|c|c|c|c|c|}
\hline \multirow[t]{3}{*}{ Gene } & \multicolumn{3}{|c|}{ Main Function } & \multirow{3}{*}{$A \beta 42$} & \multirow{3}{*}{ + DHA } & \multirow{3}{*}{ + NPD1 } \\
\hline & \multicolumn{2}{|c|}{ Apoptotic } & Inflammatory & & & \\
\hline & Pro- & Anti- & & & & \\
\hline$I L-1 \beta$ & + & & + & +4.1 & NS & NS \\
\hline CEX-1 & + & & + & +5.7 & NS & NS \\
\hline$B f l-1(A 1)$ & & + & & NS & +3.9 & +5.7 \\
\hline $\mathrm{Bcl}-2$ & & + & & NS & +2.5 & +3.3 \\
\hline$B c l-x \mid$ & & + & & NS & +1.5 & +2.4 \\
\hline Bax & + & & & +3.2 & NS & NS \\
\hline Bik & + & & & +2.8 & NS & NS \\
\hline$C O X-2$ & + & & + & +5.4 & NS & NS \\
\hline B94 & + & & + & +4.2 & NS & NS \\
\hline$T N F-\alpha$ & + & & + & +4.8 & NS & NS \\
\hline
\end{tabular}

HN cells were treated with $A \beta 42, \mathrm{DHA}$, or NPD1. Increases for A $\beta 42-$, DHA-, or NPD1-treated HN cells are expressed as fold increases over untreated, age-matched controls. CEX-1 (GenBank U64197) is a marker for inflammatory and oxidative stress responses $(4,33)$, and $B 94$ (GenBank M92357) is a TNF- $\alpha$-inducible proinflammatory element $(33,34)$. Genes are classified according to major functions although many have multiple cellular roles. Analytical criteria were gene changes of at least 2-fold over control and $P$ less than 0.05 (ANOVA) in A $342-$ stressed HN cells. NS, no significant change.

trols, respectively, and Bfl-1(A1) reached the highest significance of any upregulated gene in NPD1-treated HN cells (Figure 3). Subtraction of DHA from NPD1 DNA-array signals revealed an additional 56 genes that were upregulated 2 -fold or greater over controls $(P<0.05)$. These genes included those encoding 6 membrane receptors, 5 transcription factors, 5 kinase/phosphatase/phosphodiesterases, 2 oxygenase/ oxidoreductases, and 12 novel expressed sequence tags of unknown function (see Supplemental Table 1; available online with this article; doi:10.1172/ JCI25420DS1). To confirm changes in Bcl-2 familymember proteins, Western immunoblot analysis was performed using antiBcl-2, anti-Bfl-1(A1), and anti-actin primary antibodies (Figure 4D). After DHA treatment, Bcl-2 protein was upregulated almost 2-fold over controls, and after NPD1 treatment, Bcl-2 and Bfl-1(A1) showed highly significant upregulation, averaging 2.3fold and 3.4-fold increases, respectively, over untreated controls (Figure 4E; each $P<0.05)$. Taken together, the results suggest that

Table 2 2 -fold $(P<0.05)$ over age-matched controls.
DHA and NPD1 induce a gene-expression program that is neuroprotective through downregulation of proapoptotic and proinflammatory factors and upregulation of the Bcl-2 family of antiapoptotic proteins that are critical integral regulators of cell survival.

DHA and NPD1 content is decreased in the cornu ammonis region 1 of the hippocampus from $A D$ patients. To further investigate the possible significance of DHA-derived NPD1, we examined the levels of these bioactive lipids in $\mathrm{AD}$ hippocampal cornu ammonis region 1 of hippocampus (CA1), a brain region specifically targeted by $\operatorname{AD}$ neuropathology $(28,34,38)$. According to the plaque and tangle count (Table 2), all except $1 \mathrm{AD}$ brain sample were from $\mathrm{AD}$ patients at a moderate stage of disease development. While there were no significant differences in the age or postmortem sampling interval between the $\mathrm{AD}$ and control brain groups, and no significant differences in the RNA yields or spectral quality between AD and control groups (Table 2; ref. 34; Methods), unesterified DHA pool sizes in controls were 2-fold higher than in AD hippocampus, and NPD1 levels in AD were on average about one-twentieth of those in age-matched controls (Figure 5, A-C). Quantitative morphometric analysis of $\mathrm{AD}$ brains shows a dropout of neurons; depending on brain region and stage of disease development, the population of neurons remaining in $\mathrm{AD}$ brain has been estimated to range from $59 \%$ (39), to $77 \%$ (40), to $89 \%$ (41) of age-matched controls for the same brain region. Thus, we would argue that the loss of $11-41 \%$ of neurons is insufficient to account for the observed 20-fold reduction in the amount of NPD1 in AD hippocampus when compared with age-matched controls. The results indicate that in AD brain, despite modestly decreased availability of unesterified DHA, NPD1 levels were dramatically reduced, perhaps as the result of excessive oxidative stress, and NPD1's neuroprotective bioactivity during brain cell degeneration may be effectively lost. In these same human CA1 hippocampal samples, we also examined the levels of expression of a cytosolic

CPLA $A_{2}$ and 15-LOX gene expression in control and AD hippocampal CA1

\begin{tabular}{|c|c|c|c|c|c|c|c|}
\hline Case & Age & Sex & PMI & $\begin{array}{l}\text { Plaque-tangle } \\
\text { count }\end{array}$ & RNA & $\begin{array}{c}\mathrm{CPLA}_{2} \\
\text { (D38178) }\end{array}$ & $\begin{array}{c}\text { 15-LOX } \\
\text { (M23892) }\end{array}$ \\
\hline Control 1 & 70 & M & 1.3 & $0 / 5$ & 2.0 & +856 & $+1,634$ \\
\hline Control 2 & 69 & M & 3.0 & $0 / 2$ & 2.1 & $+2,111$ & $+1,094$ \\
\hline Control 3 & 68 & $\mathrm{~F}$ & 2.0 & $1 / 2$ & 1.9 & $+1,220$ & +102 \\
\hline Control 4 & 71 & $\mathrm{~F}$ & 1.5 & $0 / 4$ & 2.1 & $+1,810$ & $+1,235$ \\
\hline Control 5 & 66 & $\mathrm{~F}$ & 2.4 & $0 / 5$ & 2.0 & $+1,743$ & $+1,150$ \\
\hline Control 6 & 70 & M & 2.5 & $1 / 2$ & 1.9 & $+1,338$ & +950 \\
\hline Range & $66-71$ & $3 \mathrm{~F}, 3 \mathrm{M}$ & $1.3-3.0$ & - & - & +856 to $+2,111$ & +102 to $+1,634$ \\
\hline Mean \pm SD & $69.0 \pm 1.8$ & & $2.1 \pm 0.6$ & - & - & $+1,513 \pm 458$ & $+1,027 \pm 508$ \\
\hline Alzheimer 1 & 68 & $\mathrm{~F}$ & 1.5 & $8 / 15$ & 2.0 & $+8,324$ & $-1,131$ \\
\hline Alzheimer 2 & 72 & M & 2.3 & $6 / 13$ & 2.0 & $+1,870$ & -404 \\
\hline Alzheimer 3 & 70 & $\mathrm{~F}$ & 1.3 & $7 / 12$ & 2.0 & $+9,568$ & $-1,944$ \\
\hline Alzheimer 4 & 67 & $M$ & 2.1 & $6 / 14$ & 2.1 & $+8,566$ & -211 \\
\hline Alzheimer 5 & 69 & $\mathrm{~F}$ & 1.6 & $8 / 10$ & 2.0 & $+4,358$ & -704 \\
\hline Alzheimer 6 & 76 & M & 3.0 & Severe & 1.9 & $+9,020$ & $-1,442$ \\
\hline Range & $67-76$ & $3 \mathrm{~F}, 3 \mathrm{M}$ & $1.3-3.0$ & - & - & $+1,870$ to $+9,568$ & $-1,944$ to -211 \\
\hline Mean \pm SD & $70.3 \pm 3.3$ & & $2.0 \pm 0.6$ & - & - & $+6,951 \pm 2,712$ & $-973 \pm 557$ \\
\hline
\end{tabular}

Control individuals and AD patients 1-6 were previously described (33). PMI, postmortem interval, hours. Plaquetangle count, average lesion density per square millimeter. Numbers in the RNA column are indices for RNA spectral purity and represent the ratio of spectral absorbance at $260 \mathrm{~nm} / 280 \mathrm{~nm}(3,33)$. Numbers in the cPLA 2 and $15-\mathrm{LOX}$ columns are mean data scores for each case using Affymetrix Data Mining and GeneSpring algorithms (Silicon Genetics); in $\mathrm{AD}$, average $\mathrm{cPLA} 2$ RNA levels were increased 4.5 -fold $(P<0.02)$ and 15-LOX levels were decreased approximately 


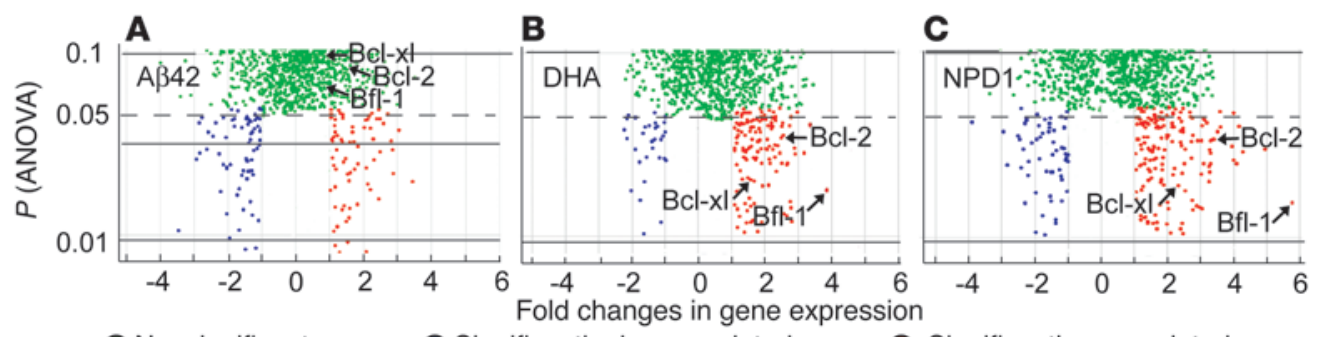

O Nonsignificant genes $\bigcirc$ Significantly downregulated genes $\bigcirc$ Significantly upregulated genes D CON AB42 DHA NPD1

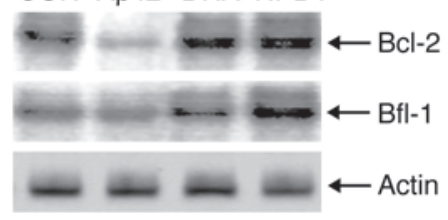

\section{Figure 4}

Changes in gene expression in HN cells in the presence of A $\beta 42(\mathbf{A})$, DHA (B), and NPD1 (C). Truncated volcano plots display gene-expression patterns as a function of fold change over age-matched controls, against $P$ (ANOVA). "Nonsignificant genes" that would normally appear in the region of $P<0.05$ and fold change of less than 1.0 (either up- or downregulated) have been omitted for clarity. Genes of highest statistical significance are sequestered into the lower left (blue, downregulated) and lower right (red, upregulated) quadrants; further data for a select group of 10 highly significant up- and downregulated genes appear in Table 1 and in Supplemental Table 1. (D) Western immunoblot analysis confirmed upregulation of Bcl-2 and Bfl-1(A1) antiapoptotic proteins over actin controls in DHA- and NPD1-treated cells. Gene transcripts have been classified according to their known major functions, although most of these RNAs may have multiple cellular functions (33). (E) Quantified intensities of Bcl-2 and Bfl-1(A1) bands normalized to constitutively expressed actin in the same sample are shown as bar graphs. ${ }^{*} P<0.02$ versus controls.

(AD samples 1-4; Table 2) averaged greater than 6.7 lesions $/ \mathrm{mm}^{2}$ (Table 2).

$\mathrm{A} \beta 42$ is a weak inducer of NPD1 and potentiates DHA ability to stimulate the synthesis of this lipid (Figure $1 \mathrm{H}$ ). The neuroprotective sAPP $\alpha$ peptide was a potent agonist for NPD1 synthesis. $\mathrm{A} \beta 42$ induces proinflammatory and proapoptotic genes, whereas DHA, and, more strikingly, NPD1, enhanced antiinflammatory and antiapoptotic gene expression. Notably, Bfl-1(A1) gene expression was upregulated by NPD1 about 6-fold in HN cells. cPLA 2 expression was increased, whereas 15-LOX, the candidate enzyme for NPD1 synthesis, was decreased in the CA1 region of hippocampi from patients with moderate to severe stages of $\mathrm{AD}$. In this same brain region, NPD1 content was dramatically reduced.

The aging of HN cells in primary culture is accompa-

$\mathrm{PLA}_{2}$ (cPLA $)$ (GenBank D38178; encoding an 82.5-kDa, calcium-dependent $\mathrm{CPLA}_{2}$ ) and 15-LOX (GenBank M23892; encoding 15-lipoxygenase), 2 key enzymes in the mobilization of DHA and NPD1 biosynthesis (Figure 5D). In AD brain, when compared with age-matched controls, $\mathrm{CPLA}_{2}$ abundance was increased 4.6-fold $(P<0.02)$ and 15-LOX decreased almost 2 -fold $(P<0.05)$ (Table 2). Decreased abundance of NPD1 in AD brain may be explained, at least in part, by a disruption in the expression and regulation of the $\mathrm{PLA}_{2}$ and/or 15-LOX-like enzymes essential for NPD1 biosynthesis (Figure 5).

\section{Discussion}

Here we have demonstrated that DHA decreased $A \beta 40$ and $A \beta 42$ peptide secretion from aging brain cells and that this was accompanied by biosynthesis of NPD1. In turn, NPD1 inhibited A $\beta 42-$ induced apoptosis. Our observations on the occurrence of apoptosis in both glial and neuronal cell populations in our stressed $\mathrm{HN}$ cell model are in concordance with the findings of others on apoptosis in glial and neuronal cells in AD brain (42-44). The neuropathologic features of the CA1 region for the control and $\mathrm{AD}$ samples used in this study, including age, sex, postmortem interval, and senile plaque and neurofibrillary tangle densities, are summarized in Table 2; additional neuropathologic parameters for these same tissues (tissue $\mathrm{pH}$, clinical dementia rating, etc.) were presented in a recent publication (33). Concerning the brain samples used for lipidomic analysis, while the senile plaque densities in the CA1 region for control tissues used (control samples 1-4; Table 2) averaged 0.25 lesions $/ \mathrm{mm}^{2}$, the senile plaque densities in the CA1 for all AD tissues used in the lipidomic study nied by the release of $A \beta 40$ and $A \beta 42$ peptides into the cell culture medium, and for each $A \beta$ peptide this secretion increases almost 8 -fold over 8 weeks of culture (Figure 1, D and E). Importantly, we observed no significant change in neuronal and glial cell morphology in these cultures after 18 hours of A $\beta 42$ (or NPD1) treatment, and there was no considerable cell death at the concentrations of $A \beta 42$ used over the time course investigated (Figure 2). This suggests that $A \beta 42$ is setting in motion potential cell-damaging signals accompanied by the early onset of apoptosis, and changes in gene-expression patterns that may be in part emulating the neurodegenerative process characteristic of AD. Accumulation of secreted $A \beta 40$ and $A \beta 42$ peptides during $H N$ cell aging has important implications in the development of $A \beta$-related neuropathology and resembles $A \beta$ deposition observed during brain aging and in AD (39-41). Intracellular processing of the transmembrane glycoprotein $\beta$ APP through a sequential $\beta$ - and $\gamma$-secretase-catalyzed proteolysis generates $A \beta$ peptides that are subsequently shuttled to the plasma membrane and secreted $(26,29)$. Interestingly, exposure of HN cells to the glial cell-derived, proinflammatory cytokine IL- $1 \beta$ significantly stimulated both A $\beta 40$ and $A \beta 42$ secretion as a function of $H N$ cell aging. IL- $1 \beta$ directly stimulates $\gamma$-secretase-mediated cleavage of $\beta$ APP into A $\beta$ peptides through a JNK-dependent MAPK pathway (34). Conversely, in the present work, instillation of DHA into the HN cell culture medium suppressed both $A \beta 40$ and $A \beta 42$ peptide release. DHA attenuates increases in the levels of lipid peroxides and reactive oxygen species in the cerebral cortex and the hippocampus of $\mathrm{A} \beta$-infused rats, suggesting that DHA elicits neuroprotection by blocking $A \beta 40 / A \beta 42$ neurotoxicity $(45,46)$. This protection might 
A
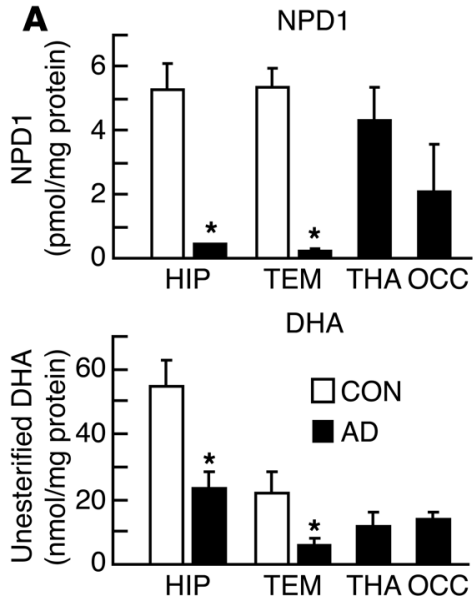

C

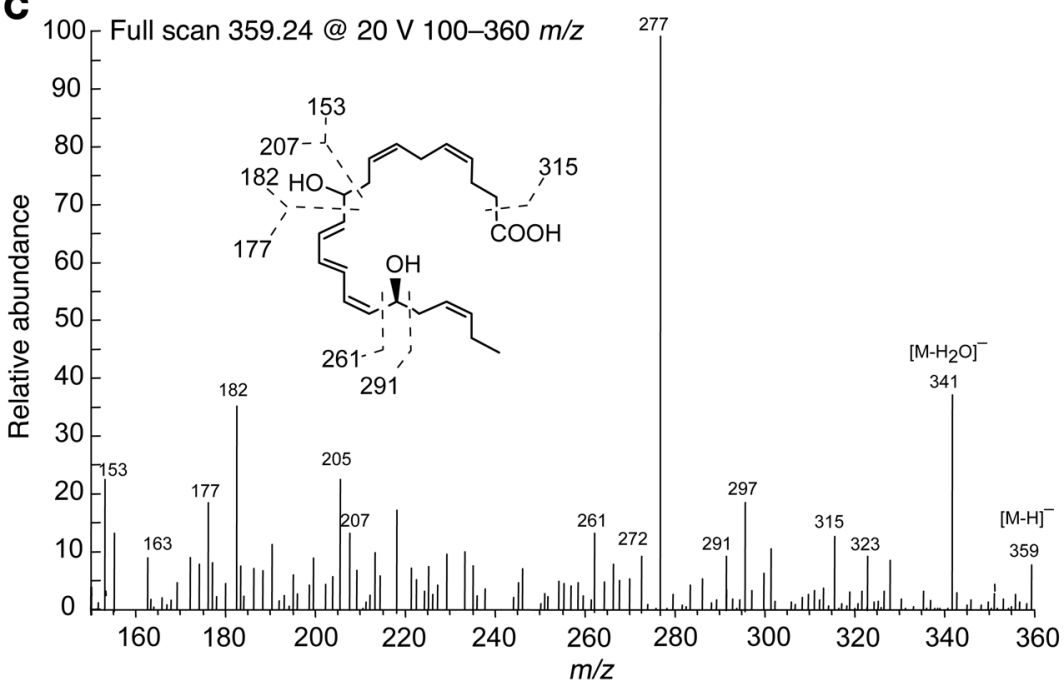

B 100 SRM $359.24 @ 20$ V $153 \mathrm{~m} / \mathrm{z}$

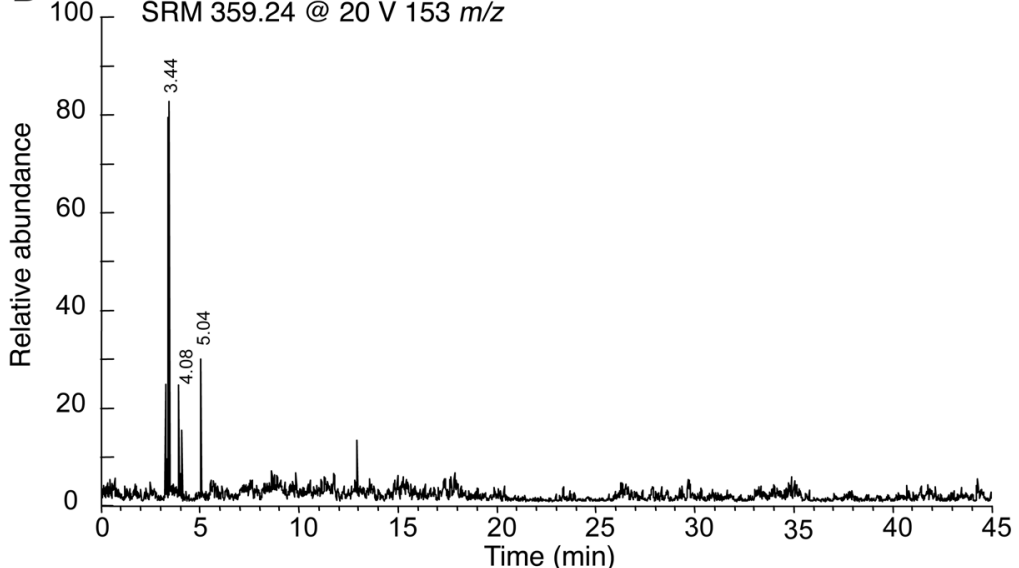

D

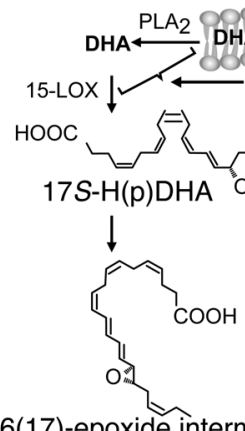

16(17)-epoxide intermediate<smiles>CC1CCCC(C)C1C(=O)O</smiles>

10,17S-Docosatriene (Neuroprotectin D1, NPD1)

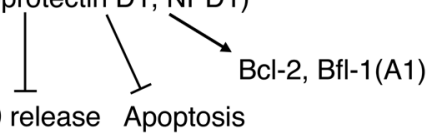

A 440 release Apoptosis

$A \beta 42$ release

\section{Figure 5}

NPD1 and DHA are reduced in AD brain. (A) When compared with age-matched controls, NPD1 and unesterified DHA were significantly reduced in $A D$ hippocampus (HIP) and temporal lobe (TEM) but not in the thalamus (THA) or occipital lobe (OCC) of the same AD brains. In AD, thalamic and occipital regions were relatively spared AD neuropathology. Signals for NPD1 and unesterified DHA in AD hippocampus averaged about one-twentieth and one-half, respectively, of those values seen in age-matched controls. LC-PDA-ESI-MS-MS-based lipidomic analysis (sensitivity $0.05 \mathrm{pmol} / \mathrm{mg}$ total protein). $n=6$. ${ }^{\star} P<0.01$ (ANOVA). (B) Characterization of NPD1 using LC-PDA-ESI-MS-MS-based lipidomic analysis $(5,6)$. (C) Mass spectrographic identification of 10,17S-docosatriene (NPD1) in human hippocampus. (D) Proposed biosynthetic pathways from DHA to NPD1 and bioactivity. DHA is highly enriched as an acyl side chain of brain and retinal membrane phospholipids, suggesting its impor-

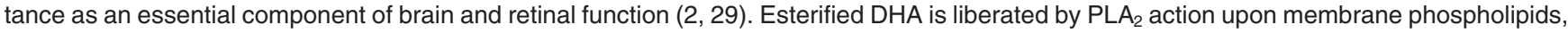
whereupon it is oxygenated, initially via a 15-LOX-like enzyme, into 10,17S-docosatriene (NPD1). sAPP $\alpha$, a secreted neurotrophic peptide, stimulates NPD1 biosynthesis. NPD1 exhibits neuroprotective activity against A $\beta 42$ action, represses apoptosis, and promotes the expression of antiapoptotic genes encoding Bcl-2 and Bfl-1(A1) (37).

be achieved by decreasing $\gamma$-secretase activation, by decreasing antioxidative defenses, or both $(22,46)$. Along those lines, recent studies indicate that DHA attenuates neuronal degeneration and rescues learning ability in rodent models of $\mathrm{AD}(22,45,46)$. Moreover, the neuroprotective mediator NPD1 $(2,5,6)$ is formed, while DHA downregulates $A \beta$ release in aging $\mathrm{HN}$ cells in culture (Figure 1). Since NPD1 inhibits A $\beta 42$-induced apoptosis in $\mathrm{HN}$ cells (Figure 2), DHA protection in cells in culture and in in vivo models may involve NPD1 synthesis.
Striking changes in the expression of $\mathrm{Bcl}-2$ family members correlate with A $\beta 42$, DHA, or NPD1 exposure. Pro- and antiapoptotic proteins are modulators proximal to mitochondria and irreversible cell damage. Proapoptotic proteins Bik and Bax were enhanced by $\mathrm{A} \beta 42$, but not by DHA or NPD1, whereas Bcl-2, Bcl-xl, and Bfl-1(A1) were enhanced in the presence of DHA. NPD1, on the other hand, promoted a much larger increase in antiapoptotic $\mathrm{Bcl}-2$ proteins. Bfl-1(A1) increased almost 6-fold. Antiapoptotic Bcl-2 family members such as Bfl-1(A1) play critical roles in the survival of aged 
and terminally differentiated cells and break the mechanistic link between inflammatory signaling and apoptosis (37). In fact, NPD1 also induces the antiapoptotic $\mathrm{Bcl}-2$ family proteins $\mathrm{Bcl}-2$ and $\mathrm{Bcl}-$ $\mathrm{xl}$ in oxidatively challenged human retinal pigment epithelial cells (6) and promotes cytoprotection. A further suggestion of the significance of NPD 1 in AD is the observation that hippocampal CA1 from $A D$ patients shows a dramatic reduction in NPD1. Whether decreased NPD1 levels in AD brain hippocampal CA1 are the result or the cause of the $\mathrm{AD}$ process remains to be clarified. All except 1 postmortem AD brains displayed moderate histopathologic changes (Table 2). Since these tissues were sampled within 3 hours postmortem, the NPD1 pool size may reflect the capacity of the CA1 hippocampal region to activate synthesis of the mediator. In mouse brain undergoing ischemia/reperfusion, NPD1 increases during the initial 8 hours after 1 hour of ischemia (5). In the postmortem brain, the differences found between age-matched controls and AD brains point to the relative inability of the AD CA1 region to accumulate NPD1.

In summary, the interplay of DHA-derived neuroprotective signaling aims to counteract proinflammatory, cell-damaging events triggered by multiple, converging cytokine and amyloid peptide factors in AD. Amyloid peptide-mediated oxidative stress, the activation of microglia associated with $\mathrm{A} \beta$ peptide deposition, and excessive production of microglial-derived cytokines such as IL-1 $\beta$ and TNF- $\alpha$ support progressive inflammatory episodes in AD $(4,32,38,47)$. These noxious stimuli further orchestrate pathogenic gene-expression programs in stressed brain cells, thereby linking a cascade of caspase-mediated cell death pathways with apoptosis and neuronal demise $(3,33,48)$. Neural mechanisms leading toward NPD1 generation from DHA thereby appear to redirect cellular fate toward successful brain cell aging. The Bcl-2 pro- and antiapoptotic gene families, sAPP $\alpha$, and NPD1 lie along a cell fate-regulatory pathway whose component members are highly interactive, and have potential to function cooperatively in brain cell survival, acting through modulation of $A \beta 42$-directed pathogenic events. Taken together, these data suggest that NPD1 induces an antiapoptotic, neuroprotective gene-expression program that regulates the secretion of $A \beta$ peptides, resulting in the modulation of inflammatory signaling, neuronal survival, and the preservation of brain cell function. Agonists of NPD1 biosynthesis or NPD1 analogs may be useful for exploring new therapeutic strategies for $\mathrm{AD}$ and related neurodegenerative disease.

\section{Methods}

Reagents, inducers, and antibodies. Human recombinant IL-1 $\beta$ (I4019) and DHA (D2534) were purchased from Sigma-Aldrich. HN cells, HNMM, and bullet packs containing human epidermal and fibroblast growth factor (E/FGF), gentamicin/amphotericin (G/A1000), neural survival factor-1 (NSF-1), and FBS were obtained from Cambrex Corp. Human-specific antiA 440 (A8326), anti-A 42 (A1976), anti-Bcl-2 (B3170), anti-actin (A2103), anti- $\beta$ III tubulin (T8660) and anti-GFAP (G9269) primary antibodies were obtained from Sigma-Aldrich. Anti-Bfl-1(A1) (sc-8351) was obtained from Santa Cruz Biotechnology Inc. Hoechst 33258 pentahydrate (benzimide) (H-1398) was obtained from Invitrogen Corp. NPD1, prepared and quantified according to reported physical and biological properties (49), was used at $50 \mathrm{nM}$. All other reagents were of the highest grades commercially available and were used without further purification.

HN cells in primary culture. Starting as primary spheroids, HN cells (CC-2599; Cambrex Corp.) were grown in a modified HNMM containing human $\mathrm{E} / \mathrm{FGF}, \mathrm{G} / \mathrm{A} 1000$, NSF-1, and 5\% FBS from 0 to 8 weeks
(Figure 1A). HN cells displayed approximately equal populations of neurons and glia after 4 weeks of development and stained positive with a red, neuron-specific marker, $\beta I I I$ tubulin (Figure 1B), and the green, gliaspecific marker GFAP (25) (Figure $1 C$ ). In A $\beta$ peptide secretion experiments, after 1 week of cell growth, IL-1 $\beta(10 \mathrm{ng} / \mathrm{ml})$ or DHA $(50 \mathrm{nM})$ was continuously present in the HNMM. NPD1 was prepared and quantified according to reported physical and biological properties (49). Modified HNMM, with or without additives, was changed every 3.5 days, and the concentration of $A \beta 40$ and $A \beta 42$ peptides was assayed every 7 days after concentrating medium using Centricon spin columns (Millipore) followed by protein analysis using Tris-glycine-SDS gel electrophoresis and Western immunoblot assay $(3,50)$.

Human CA1 hippocampal regions. Protocols for experimental use of brain tissues were reviewed and approved by the Institutional Review Boards of Louisiana State University Health Sciences Center and the Oregon Health Sciences Center (Portland, Oregon, USA). Control $(n=6)$ or $\mathrm{AD}(n=6)$ samples encompassing the cornu ammonis 1 (CA1), superior temporal lobe, thalamus, or occipital cortex exhibited no significant differences in age $(69.0 \pm 1.5$ versus $70.3 \pm 1.9$ years, $P<0.87)$, postmortem interval $(2.1 \pm 0.7$ versus $2.0 \pm 0.7$ hours, $P<0.96)$, or tissue $\mathrm{pH}$ $(6.75 \pm 0.1$ versus $6.76 \pm 0.1, P<0.98)$, control versus $A D$, respectively (Table 1). Total protein was determined using dotMETRIC protein microassay (Chemicon International; sensitivity $0.3 \mathrm{ng}$ protein $/ \mathrm{ml}$ ) using brain nucleoprotein as a standard (3).

Western analysis and immunocytochemistry. The presence of 2 neurotoxic forms of $A \beta$ peptide, $A \beta 40$ and $A \beta 42$, was monitored using Western immunoblot analysis of HNMM essentially as described (50). Bcl-2 family proteins were detected in total $\mathrm{HN}$ cell lysates by analysis of $25-\mu \mathrm{g}$ samples using Western immunoblot analysis and human-specific anti-A $\beta 40,-\mathrm{A} \beta 42$, -Bcl-2,-Bfl-1(A1), and -actin primary antibodies (3). Western signal-intensity data were gathered by phosphor imaging onto molecular imaging screens using a Typhoon (Amersham Biosciences) molecular imaging system (3). Hoechst 33258 staining for apoptotic HN cell nuclei exhibiting DNA degradation was quantified as previously described using a Nikon Corp. DIAPHOT 200 microscope under UV fluorescence (6).

Lipidomic analysis of brain and cell lines. Lipids were extracted by homogenization of cells or tissues in chloroform/methanol solutions and stored under nitrogen at $-80^{\circ} \mathrm{C}(1,2)$. For signal quantification, lipid extracts were supplemented with deuterated labeled internal standards, purified by solid-phase extraction, and loaded onto a BioBasic AX column (Thermo Electron Corp.; $100 \mathrm{~mm} \times 2.1 \mathrm{~mm} ; 5$ - $\mu \mathrm{m}$ particle sizes) run with a 45 -minute gradient protocol, starting with solvent solution A (40:60:0.01 methanol/water/acetic acid, $\mathrm{pH} 4.5 ; 300 \mu \mathrm{l} / \mathrm{min}$ ); the gradient typically reached $100 \%$ solvent B (99.99:0.01 methanol/acetic acid) in 30 minutes and was then run isocratically for 5 minutes. A TSQ Quantum (Thermo Electron Corp.) triple quadrupole mass spectrometer and electrospray ionization was used with spray voltage of $3 \mathrm{kV}$ and $\mathrm{N}_{2}$ sheath gas $\left(35 \mathrm{~cm}^{3} / \mathrm{min}, 350^{\circ} \mathrm{C}\right)$. Parent ions were detected on full-scan mode on the Q1 quadrupole. Quantitative analysis was performed by selective reaction monitoring. The $\mathrm{Q} 2$ collision gas was argon at $1.5 \mathrm{mTorr}$, and daughter ions were detected on Q3. Selected parent/daughter ion pairs for NPD1 and unesterified DHA were typically 359:153 m/z and 327:283 m/z, respectively. Calibration curves for NPD1 and DHA (Cayman Chemical Co.) were obtained. NPD1 was generated via biogenic synthesis using soybean lipoxygenase and DHA, purified by HPLC, and characterized by LCPDA-ESI-MS-MS according to reported biophysical criteria $(6,49)$.

RNA and protein isolation and quality control. HN cells or human brain tissues were rapidly processed and total RNA and protein were extracted using TRIzol reagent (Invitrogen Corp.). Use of RNase-free plasticware and extraction reagents containing RNAsecure (Ambion Inc.) ribonuclease 
inhibitors yielded high-spectral quality RNA as analyzed using RNA LabChip Analysis Chips (Caliper Life Sciences Inc.) and a 2100 Bioanalyzer (Agilent Technologies). $\mathrm{A}_{260} / \mathrm{A}_{280}$ and $28 \mathrm{~S} / 18 \mathrm{~S}$ for each total RNA sample were typically greater than 1.9 and greater than 1.5 , respectively. There were no significant differences in the total RNA yield or RNA spectral quality between the control and $\mathrm{AD}$ brain groups.

Probe synthesis and GeneChip hybridization. Biotinylated antisense cRNAs were synthesized from cDNA using the Superscript Choice System (Invitrogen Corp.), Enzo BioArray HighYield RNA Transcript Labeling kits (Enzo Biochem), and the manufacturer's protocols (Affymetrix) $(3,33)$. Probes were hybridized against HG U95Av2 or HG U133A GeneChip DNA arrays (Affymetrix) that interrogate gene expression in approximately 12,000 and 33,000, respectively, full-length human genes and expressed sequence tag clusters. Methodologies for first- and second-strand synthesis and conversion of double-stranded cDNA into biotinylated antisense cRNA, probe fragmentation, hybridization, washing, and staining with streptavidin-R phycoerythrin (Invitrogen Corp.) and biotinylated goat antistreptavidin antibody (Sigma-Aldrich) were described previously (33).

GeneChip data and statistical analysis. DNA arrays were scanned at 570 $\mathrm{nm}$, and features were extracted and plotted using Data Mining Tool 3.0 (Affymetrix), Microarray Suite 5.0 (Affymetrix), and GeneSpring 7.2 algorithms (Silicon Genetics). Volcano plots were used to represent total geneexpression patterns as a function of fold change over controls, against $P$ (ANOVA). In this analysis we used a stringent cutoff for genes that had a more than 2.0-fold change (in A_42-treated cells), either increased or decreased over controls, that achieved a $P$ less than 0.05 . "Fold change" refers to comparison of the means of DHA- or NPD1-treated and control $\mathrm{HN}$ cells or AD and age-matched neurologically normal brain. Statistical significance was analyzed using a 2-way factorial analysis of variance ( $P$, ANOVA; Statistical Analysis System; SAS Institute Inc.). Microscope images were recorded and analyzed using a Hamamatsu Color Chilled 3CCD camera (Hamamatsu Photonics) and Adobe Photoshop 6.0 software (Adobe Systems Inc.).

\section{Acknowledgments}

This work was funded by US Public Health Service grants AG18031 from the National Institute on Aging (to W.J. Lukiw), GM38765 from the National Institute of General Medical Sciences (to C.N. Serhan), RR16816 from the Centers of Biomedical Research Excellence program of the National Center for Research Resources, and NS23002 and NS46741 from the National Institute of Neurological Disorders and Stroke (to N.G. Bazan).

Received for publication April 20, 2005, and accepted in revised form June 28, 2005.

Address correspondence to: Nicolas G. Bazan or Walter J. Lukiw, Louisiana State University Neuroscience Center of Excellence, 2020 Gravier Street, Suite D, New Orleans, Louisiana 70112, USA. Phone: (504) 599-0831; Fax: (504) 568-5801; E-mail: nbazan@lsuhsc.edu (N.G. Bazan). Phone: (504) 599-0842; Fax: (504) 568-5801; E-mail:wlukiw@lsuhsc.edu (W.J. Lukiw).
1. Xu, J., et al. 2001. Amyloid-beta peptides are cytotoxic to oligodendrocytes. J. Neurosci. 21:RC118.

2. Bazan, N.G. 2005. Neuroprotectin D1 (NPD1): a DHA-derived mediator that protects brain and retina against cell injury-induced oxidative stress [review]. Brain Pathol. 15:159-166.

3. Bazan, N.G., and Lukiw, W.J. 2002. Cyclooxygenase2 and presenilin-1 gene expression induced by interleukin-1beta and amyloid beta 42 peptide is potentiated by hypoxia in primary human neural cells. J. Biol. Chem. 277:30359-30367.

4. McGeer, E.G., and McGeer, P.L. 2003. Inflammatory processes in Alzheimer's disease [review]. Prog. Neuropsychopharmacol. Biol. Psychiatry. 27:741-749.

5. Marcheselli, V.L., et al. 2003. Novel docosanoids inhibit brain ischemia-reperfusion-mediated leukocyte infiltration and pro-inflammatory gene expression. J. Biol. Chem. 278:43807-43817.

6. Mukherjee, P.K., Marcheselli, V.L., Serhan, C.N., and Bazan, N.G. 2004. Neuroprotectin D1: a docosahexaenoic acid-derived docosatriene protects human retinal pigment epithelial cells from oxidative stress. Proc. Natl. Acad. Sci. U. S. A. 101:8491-8496.

7. Soderberg, M., Edlund, C., Kristensson, K., and Dallner, G. 1991. Fatty acid composition of brain phospholipids in aging and in Alzheimer's disease. Lipids. 26:421-425.

8. Prasad, M.R., Lovell, M.A., Yatin, M., Dhillon, H., and Markesbery, W.R. 1998. Regional membrane phospholipid alterations in Alzheimer's disease. Neurochem. Res. 23:81-88.

9. Nourooz-Zadeh, J., Liu, E.H., Yhlen, B., Anggard, E.E., and Halliwell, B. 1999. F4-isoprostanes as specific marker of docosahexaenoic acid peroxidation in Alzheimer's disease. J. Neurochem. 72:734-740.

10. Montine, T.J., et al. 2002. Lipid peroxidation in aging brain and Alzheimer's disease. Free Radic. Biol. Med. 33:620-626.

11. Scott, B.L., and Bazan, N.G. 1989. Membrane docosahexaenoate is supplied to the developing brain and retina by the liver. Proc. Natl. Acad. Sci. U. S. A. 86:2903-2907.
12. Suzuki, H., Park, S.J., Tamura, M., and Ando, S. 1998. Effect of the long-term feeding of dietary lipids on the learning ability, fatty acid composition of brain stem phospholipids and synaptic membrane fluidity in adult mice: a comparison of sardine oil diet with palm oil diet. Mech. Ageing Dev. 101:119-128.

13. Kyle, D.J., Schaefer, E., Patton, G., and Beiser, A. 1999. Low serum docosahexaenoic acid is a significant risk factor for Alzheimer's dementia. Lipids. 34(Suppl.):S245

14. Gamoh, S., Hashimoto, M., Hossain, S., and Masumura, S. 2001. Chronic administration of docosahexaenoic acid improves the performance of radial arm maze task in aged rats. Clin. Exp. Pharmacol. Physiol. 28:266-270.

15. Ikemoto, A., et al. 2001. Reversibility of n-3 fatty acid deficiency-induced alterations of learning behavior in the rat: level of n-6 fatty acids as another critical factor. J. Lipid Res. 42:1655-1663.

16. Catalan, J., et al. 2002. Cognitive deficits in docosahexaenoic acid-deficient rats. Behav. Neurosci. 116:1022-1031.

17. Kalmijn, S., et al. 1997. Dietary fat intake and the risk of incident dementia in the Rotterdam study. Ann. Neurol. 42:776-782.

18. Barberger-Gateau, P., et al. 2002. Fish, meat, and risk of dementia: cohort study. BMJ. 325:932-933.

19. Grant, W.B., Campbell, A., Itzhaki, R.F., and Savory, J. 2002. The significance of environmental factors in the etiology of Alzheimer's disease. J. Alzheimers Dis. 4:179-189.

20. Yamada, T., et al. 2002. Prevalence of dementia in the older Japanese-Brazilian population. Psychiatry Clin. Neurosci. 56:71-75.

21. Morris, M.C., et al. 2003. Consumption of fish and n-3 fatty acids and risk of incident Alzheimer disease. Arch. Neurol. 60:940-946.

22. Lim, G.P., et al. 2005. A diet enriched with the omega-3 fatty acid docosahexaenoic acid reduces amyloid burden in an aged Alzheimer mouse model. J. Neurosci. 25:3032-3040.

23. Guo, Q., Robinson, N., and Mattson, M.P. 1998.
Secreted beta-amyloid precursor protein counteracts the proapoptotic action of mutant presenilin-1 by activation of NF-kappaB and stabilization of calcium homeostasis. J. Biol. Chem. 273:12341-12351.

24. Selkoe, D., and Kopan, R. 2003. Notch and Presenilin: regulated intramembrane proteolysis links development and degeneration. Annu. Rev. Neurosci. 26:565-597.

25. Kaur, J., Dhaunsi, G.S., and Turner, R.B. 2004. Interleukin-1 and nitric oxide increase NADPH oxidase activity in human coronary artery smooth muscle cells. Med. Princ. Pract. 13:26-29.

26. Stein, T.D., and Johnson, J.A. 2003. Genetic programming by the proteolytic fragments of the amyloid precursor protein: somewhere between confusion and clarity [review]. Rev. Neurosci. 14:317-341.

27. Cheng, G., Yu, Z., Zhou, D., and Mattson, M.P. 2002. Phosphatidylinositol-3-kinase-Akt kinase and $\mathrm{p} 42 / \mathrm{p} 44$ mitogen-activated protein kinases mediate neurotrophic and excitoprotective actions of a secreted form of amyloid precursor protein. Exp. Neurol. 175:407-414.

28. Bahr, B.A., et al. 1998. Amyloid beta protein is internalized selectively by hippocampal field CA1 and causes neurons to accumulate amyloidogenic carboxyterminal fragments of the amyloid precursor protein. J. Comp. Neurol. 397:139-147.

29. Bazan, N.G. 2003. Synaptic lipid signaling: significance of polyunsaturated fatty acids and plateletactivating factor. J. Lipid Res. 44:2221-2233.

30. Wood, M.W., Segal, J.A., Mark, R.J., Ogden, A.M., and Felder, C.C. 2000. Inflammatory cytokines enhance muscarinic-mediated arachidonic acid release through p38 mitogen-activated protein kinase in A2058 cells. J. Neurochem. 74:2033-2040.

31. Webster, N.J., Green, K.N., Peers, C., and Vaughan, P.F. 2002. Altered processing of amyloid precursor protein in the human neuroblastoma SH-SY5Y by chronic hypoxia. J. Neurochem. 83:1262-1271.

32. Zhang, Y., McLaughlin, R., Goodyer, C., and LeBlanc, A. 2002. Selective cytotoxicity of intracellular amyloid beta peptide1-42 through p53 and Bax in cultured primary human neurons. 
J. Cell Biol. 156:519-529.

33. Colangelo, V., et al. 2002. Gene expression profiling of 12633 genes in Alzheimer hippocampal CA1: transcription and neurotrophic factor down-regulation and up-regulation of apoptotic and pro-inflammatory signaling. J. Neurosci. Res. 70:462-473.

34. Liao, Y.F., Wang, B.J., Cheng, H.T., Kuo, L.H., and Wolfe, M.S. 2004. Tumor necrosis factor-alpha, interleukin-1beta, and interferon-gamma stimulate gamma-secretase-mediated cleavage of amyloid precursor protein through a JNK-dependent MAPK pathway. J. Biol. Chem. 279:49523-49532.

35. Akhtar, R.S., Ness, J.M., and Roth, K.A. 2004. Bcl-2 family regulation of neuronal development and neurodegeneration. Biochim. Biophys. Acta. 1644:189-203.

36. Metcalfe, A.D., et al. 2004. Expression of 11 members of the BCL-2 family of apoptosis regulatory molecules during human preimplantation embryo development and fragmentation. Mol. Reprod. Dev. 68:35-50.

37. Tarte, K., et al. 2004. The Bcl-2 family member Bfl$1 / \mathrm{A} 1$ is strongly repressed in normal and malignant plasma cells but is a potent anti-apoptotic factor for myeloma cells. Br. J. Haematol. 125:373-382

38. Kim, H.J., et al. 2003. Selective neuronal degenera- tion induced by soluble oligomeric amyloid beta protein. FASEB J. 17:118-120.

39. Terry, R.D. 1983. Cortical morphometry in Alzheimer's disease. In Biological aspects of Alzheimer's disease (Banbury report). R. Katzman, editor. Cold Spring Harbor Laboratory Press. Cold Spring Harbor, New York, USA. 95-98.

40. Crapper, D.R., Dalton, A.J., Skopitz, M., Scott, J.W., and Hachinski, V.C. 1975. Alzheimer degeneration in Down's syndrome. Arch. Neurol. 32:618-623.

41. Pelvig, D.P., Pakkenberg, H., Regeur, L., Oster, S., and Pakkenberg, B. 2003. Neocortical glial cell numbers in Alzheimer's disease. A stereological study. Dement. Geriatr. Cogn. Disord. 16:212-219.

42. Kobayashi, K., et al. 2004. Correlation between astrocyte apoptosis and Alzheimer changes in gray matter lesions in Alzheimer's disease. J. Alzheimers Dis. 6:623-632.

43. Paradisi, S., Sacchetti, B., Balduzzi, M., Gaudi, S., and Malchiodi-Albedi, F. 2004. Astrocyte modulation of in vitro beta-amyloid neurotoxicity. Glia. 46:252-260.

44. Kitamura, Y., Taniguchi, T., and Shimohama, S. 1999. Apoptotic cell death in neurons and glial cells: implications for Alzheimer's disease. Jpn. J. Pharmacol. 79:1-5.

45. Calon, F., et al. 2004. Docosahexaenoic acid pro- tects from dendritic pathology in an Alzheimer's disease mouse model. Neuron. 43:633-645.

46. Hashimoto, M., et al. 2005. Chronic administration of docosahexaenoic acid ameliorates the impairment of spatial cognition learning ability in amyloid (beta)-infused rats. J. Nutr. 135:549-555.

47. Hong, H.S., et al. 2003. Interferon gamma stimulates beta-secretase expression and sAPPbeta production in astrocytes. Biochem. Biophys. Res. Commun. 307:922-927.

48. Lahiri, D.K., Chen, D., Vivien, D., Ge, Y.W., and Greig, N.H. 2003. Role of cytokines in the gene expression of amyloid beta-protein precursor: identification of a $5^{\prime}$-UTR-binding nuclear factor and its implications in Alzheimer's disease. J. Alzheimers Dis. 5:81-90.

49. Hong, S., Gronert, K., Devchand, P.R., Moussignac, R.L., and Serhan, C.N. 2003. Novel docosatrienes and $17 \mathrm{~S}$-resolvins generated from docosahexaenoic acid in murine brain, human blood, and glial cells. Autacoids in anti-inflammation. J. Biol. Chem. 278:14677-14687.

50. Turner, R.S., Suzuki, N., Chyung, A.S., Younkin, S.G., and Lee, V.M. 1996. Amyloids beta40 and beta42 are generated intracellularly in cultured human neurons and their secretion increases with maturation. J. Biol. Chem. 271:8966-8970. 